\begin{tabular}{|c|c|c|}
\hline (1) & $\begin{array}{c}\text { Türkiye Tarımsal Araştırmalar Dergisi } \\
\text { dergipark.org.tr/tutad }\end{array}$ & $\begin{array}{l}\text { Turk J Agric Res } \\
\text { 2019, 6(3):342-348 } \\
\text { @ TÜTAD } \\
\text { ISSN: 2148-2306 }\end{array}$ \\
\hline $\begin{array}{l}\text { ÜNIVERSITESI } \\
\text { Bilimin Yüumuda }\end{array}$ & Araştırma Makalesi / Research Article & $\begin{array}{l}\text { e-ISSN: } 2528-858 \mathrm{X} \\
\text { doi: } 10.19159 / \text { tutad.626298 }\end{array}$ \\
\hline
\end{tabular}

\title{
Ar-Ge Harcamaları ve Büyüme: Türkiye Tarım Sektörü Üzerine Ampirik Bir Çalışma*
}

\author{
Bekir PAKDEMIRLi“** \\ T.C. Tarım ve Orman Bakanlığl, Ankara, TÜRKIYYE
}

\begin{abstract}
Geliş Tarihi/Received: 28.09.2019
Kabul Tarihi/Accepted: 18.11.2019

ORCID ID

(1D orcid.org/0000-0002-0336-0613

"Sorumlu Yazar/Corresponding Author: bekir@pakdemirli.com

Öz: Araştırma ve geliștirme (Ar-Ge) harcamaları inovasyonda, verimliliğin arttırılmasında ve ekonomik büyümede önemli bir rol oynamaktadır. Tarımsal üretimde de kalite ve verimliliği arttırmak için kamu ve özel sektör tarafından Ar-Ge harcamaları yapılmaktadır. Bu çalışmada; dünyada ve Türkiye'de tarımsal Ar-Ge harcamalarının mevcut durumunun ortaya konması, ayrıca Türkiye tarım sektöründe yapılan Ar-Ge harcamaları ve tarımsal hasıla arasındaki ilişkinin Granger nedensellik testi ile 2003-2017 yılları verileri kullanılarak incelenmesi amaçlanmıştır. Çalışmanın sonuçları, tarımsal Ar-Ge harcamaları ve tarımsal hasıla arasında iki yönlü bir nedensellik bulgusunu ortaya koymaktadır. Diğer bir deyişle, Ar-Ge harcamaları tarımsal hasılayı, tarımsal hasıla da Ar-Ge harcamalarını olumlu olarak etkilemektedir.
\end{abstract}

Anahtar Kelimeler: Ar-Ge, tarımsal hasıla, Granger nedensellik, Türkiye

\section{R\&D Expenditures and Growth: An Empirical Analysis on Agricultural Sector of Turkey}

\begin{abstract}
Research and development (R\&D) expenditures play an important role in innovation, increasing productivity and economic growth. R\&D expenditures are carried out by public and private sectors to increase the quality and productivity in agricultural production. This study reveals the current state of agricultural R\&D spending in the world and in Turkey. In addition, the study examines the Granger causality between the agricultural sector R\&D spending and agricultural output in Turkey by using 2003-2017 as a sample period. The results of the study reveal a two-way causality between agricultural R\&D expenditures and agricultural output. That is, $R \& D$ expenditures positively affect agricultural output and at the same time agricultural output has a positive impact on R\&D expenditures.
\end{abstract}

Keywords: R\&D, agricultural revenue, Granger causality, Turkey

\section{Giriş}

Tarımsal üretimdeki artış; gelirleri artırma, açlı̆̆ azaltma ve dünyanın gelişmekte olan birçok yerinde diğer refah artırıcı önlemlerin geliştirilmesine katkıda bulunma stratejisinin önemli bir bileşeni olarak hizmet etmektedir (Owens ve ark., 2003). Bir ülkenin ekonomik kalkınması, sanayileşmesiyle doğru orantılıdır. Ancak, tarım sektörünü geliştirmeyen ülkelerin ekonomik yönden gelişmeleri oldukça zordur. Tarım sektörü; insanların geçim kaynağı olmakta, ülke nüfusunu beslemekte, ihracata katkısıyla döviz gelirlerinin artmasına yardımcı olmakta, diğer sektörlere iş gücü ve sermaye aktarmakta, ayrıca sanayi sektörü ürünlerine pazar oluşturmaktadır (Cinemre ve Kılıç, 2015).

Son yıllarda yapılan çalışmalar, tarımsal ürünlere olan küresel talebi karşılamak için 2005 ve

": Bu çalışmanın ilk versiyonu; 25-26 Nisan 2019 tarihlerinde Alanya'da düzenlenen " $3^{\text {rd }}$ International Conference on Food and Agricultural Economics" kongresinde sözlü bildiri olarak sunulmuş olup, adı geçen kongre bildiriler kitabında özet metni yayınlanmıştır. 
2050 yılları arasında dünya tarımsal mahsul üretiminin $\% \quad 60$ ile $\% \quad 100$ oranında artmas1 gerektiğine işaret etmektedir (Tilman ve ark., 2011; Ray ve ark., 2013). Küresel gıda güvenliği, tarımsal üretkenlikteki kazanımlara artan bir şekilde bağlı olacaktır. Çünkü üretimdeki artışın, ekilebilir arazi gibi geleneksel girdilerdeki artışlardan kaynaklanması beklenmemektedir (Pardey ve ark., 2013). Arazinin yenilenemeyen bir kaynak olması da tarımda sürdürülebilir arazi kullanımını önemli hale getirmektedir (Eryılmaz ve Kılıç, 2018).

Tarımsal üretimde sürdürebilir bir verimlilik artışının yolu Ar-Ge harcamalarından geçmektedir. Andersen (2015), Amerika Birleşik Devletleri'nde 1900-2002 yılları arasında kamu tarafindan yapılan tarımsal Ar-Ge harcamalarının, tarım sektöründe anlamlı bir ekonomik getiri sağladığını ortaya koymaktadır. Alene (2010), Afrika ülkelerini incelediği kapsamlı çalışmasında, verimlilik artışının itici gücü olarak teknolojik ilerlemeyi belirtmekte ve tarımsal Ar-Ge'nin Afrika tarımında verimlilik üzerinde pozitif ve önemli bir etkisi olduğunu, 1970-2004 verilerini kullanarak göstermektedir. Gelişmiş ve gelişmekte olan 78 farklı ülkede 1958-2015 yılları arasında yapılan ve Ar-Ge harcamalarının getirilerini ortaya koyan 492 çalışmayı analiz eden Rao ve ark. (2019), Ar-Ge harcamalarının getiriler üzerinde pozitif ve anlamlı bir etkisi olduğunu belirtmektedir. $\mathrm{Bu}$ bağlamda, önümüzdeki on yıllarda artan dünya nüfusu göz önüne alındığında, yeterli gıda temininde tarımsal Ar-Ge kritik öneme sahiptir. Tüm dünyada ülkeler, özelikle yüksek gelirli olanlar, tarımsal üretkenlik için Ar-Ge harcamaları yapmaktadır. Tarımsal ArGe'ye yapılan sistematik kamu ve özel yatırımları, 20. yüzyılın ikinci yarısında yaşanan tarımsal üretkenlikte nispeten hılı büyümenin temel itici gücü olmuştur (Alston ve ark., 2009). Ülkelerin gelir düzeylerine bağlı olarak 1960-2009 yılları arası yaptıkları Ar-Ge harcamaları Gayri Safi Yurt İçi Harcamalarının (GSYİH) yüzdesi olarak Şekil 1 'de verilmiştir. Şekil 1'de görüldüğü gibi, son 50 y1l içerisinde yapılan harcamalar düzenli olarak artış göstermiş, fakat bu artış, büyük oranda yüksek gelirli ülkeler tarafından gerçekleştirilmiştir. Türkiye'nin de aralarında bulunduğu yüksek gelirli olmayan ülkeler grubu, Ar-Ge harcamalarında yüksek gelirli ülkelerin oldukça gerisinde kalmıştır.

Tarım sektörünün ülke ekonomisi içerisindeki yeri, tarımın genel ekonomi içerisinde yaratmış olduğu katma değer ile ölçülmektedir. Tarımsal faaliyetler sonucu ortaya çıkan hâsıla, tarımsal çıktı, dış ticaret, istihdam ve diğer sektörlere girdi temini gibi başlıklar bu katma değeri oluşturan unsurlardır (Doğan ve ark., 2015). Tarım sektörünün, Türkiye ekonomisi içindeki payı nisbi olarak azalsa da sayılan bu katma değer unsurlarından ötürü hala önemini korumaktadır. Tarımsal üretim ve verimlilikte sürdürülebilir büyüme, Türkiye'deki kırsal bölgelerin ekonomik refahı için de zorunludur. Bu sayede geçimini tarımdan sağlayan nüfus yerinde istihdam edilecek ve tarımsal nüfusun kırsal toplum olma özelliği korunmuş olacaktır (Eryılmaz ve ark., 2019).

Türkiye'de tarımsal araştırmanın amac1; üretimde verimi, kaliteyi, kârlılığı arttıracak ve kaynakların sürdürülebilirliğine katkıda bulunacak teknolojiler geliştirmektir (Bayaner, 2016). Türkiye tarımının genel sorunlarından birkaçı; parçalanmış arazi, küçük boyutlu işletmeler ve sonuç olarak azalan tarımsal verimliliktir. $\mathrm{Bu}$ durum, ölçek ekonomisinden faydalanamama ve karlılıkta azalma olarak neticelenmektedir. Tarımsal faaliyetler, modern tarımsal metotlar kullanan, büyük ölçekli ve alanında uzman tarım işletmeleri tarafından gerçekleştirilmelidir (Doğan ve ark, 2015). Tarımsal işletmeler, yüksek rekabet ortamında ayakta kalabilmek için yeniliklere ve

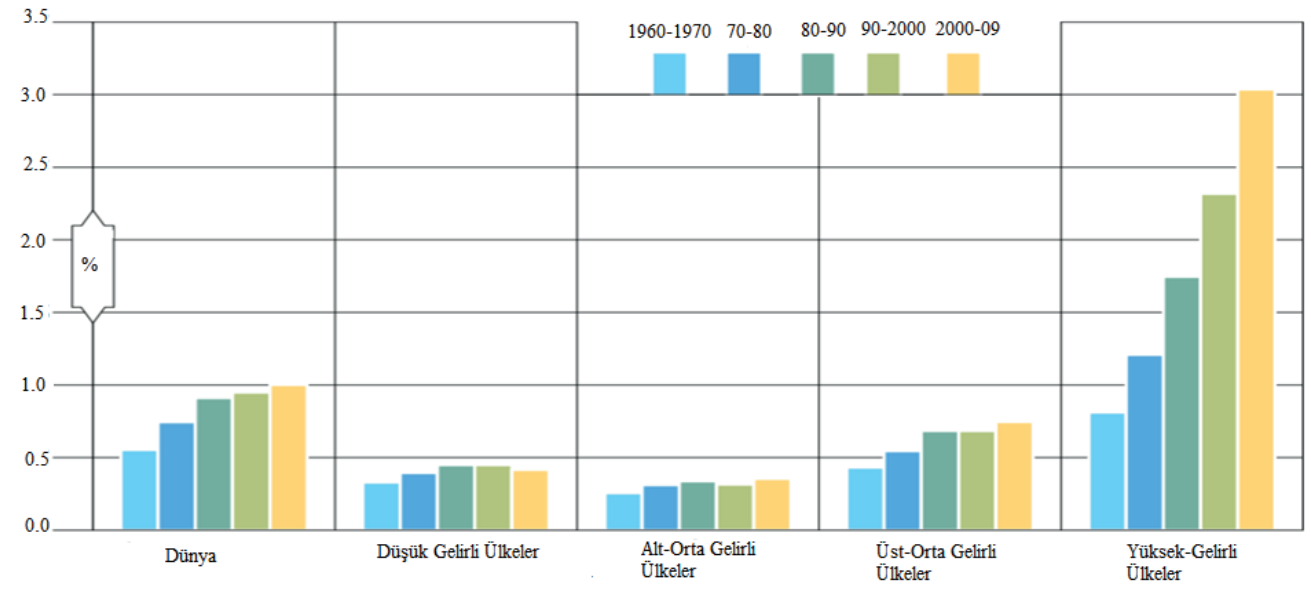

Şekil 1. Dünyada tarımsal Ar-Ge harcamaları (Tarımsal Ar-Ge harcamaları/Tarımsal GSYİH, \%)

(Anonymous, 2017) 
gelişmelere açık olmalıdır. Ar-Ge harcamaları bu noktada büyük önem taşımaktadır. Literatürde, Türkiye'de tarımsal Ar-Ge harcamaları ile ekonomik büyüme arasındaki ilişkiyi araştıran çalışmalar mevcuttur. Fakat bu araştırmalar daha çok nitel araştırmalar olmuştur. Subaşı ve Ören (2013), tarımsal Ar-Ge harcamaları ile toplam faktör verimliliği arasındaki ilişkiyi incelemekte, tarımsal Ar-Ge harcamalarının tek yönlü olarak toplam faktör verimliliğini artırdığını ortaya koymaktadır. Özaydın ve Çelik (2019), istatistiki verilerden, raporlardan ve ilgili mevzuattan yararlanarak, dünya ve Türkiye'de tarım sektörüne ait Ar-Ge faaliyetlerinin durumunu ele almış; dünyada ve Türkiye'de tarımsal Ar-Ge harcamaları ve yoğunluklarının artma eğiliminde olduğunu, fakat bu göstergelerin Türkiye için hala istenilen seviyelerde olmadığını rapor etmiştir. Aynı araştırmac1, Ar-Ge yoğunluğunun, gelişmiş ülkelerdeki \% 2 seviyesine çıartılmasını ve harcamaların yüksek katma değerli, rekabet edebilir ürün ve teknolojilerin geliştirilmesi gibi alanlarda yapılması gerektiğini bildirmiştir.

$\mathrm{Bu}$ çalışma, zaman serisi verilerini kullanarak Türkiye tarım sektöründe Ar-Ge harcamalarının önemini ortaya koymayı hedeflemektedir. Tarımsal Ar-Ge harcamaları ile tarımsal hasıla arasındaki ilişkinin daha iyi anlaşılması, tarımsal Ar-Ge için fonlama kararlarının daha sağlıklı alınması, tarımsal verimlilikte ve dolayısıyla üretim hacminde artışların sağlanmasına yardımcı olur. Çalışmada, 2003-2017 yılları arası için, değişkenler arasındaki kısa dönemli veya dinamik ilişkiler ortaya çıkarılıp, nedensel bağların yönü belirlenmiş, ayrıca değişkenler arası uzun dönemli ilişkinin varlığı da hata düzeltme modeli kullanılarak ortaya konulmuştur. Böylelikle çalışma, tarımsal Ar-Ge harcamaları ve tarımsal büyümeyi temsilen, tarımsal GSYİH arasındaki ilişkiyi ampirik olarak açıklamayı amaçlamaktadır.

\section{Materyal ve Yöntem}

\subsection{Materyal}

Çalıșmanın materyalini, 2003-2017 yılları arası tarımsal GSYİH ve tarımsal Ar-Ge harcamalarına ilişkin veriler oluşturmaktadır. Değişkenlere ait veriler Türkiye İstatistik Kurumu'ndan (TÜIK) derlenmiştir. TÜİK, Ar-Ge harcamaları verilerini ekonomik faaliyet kodu ayrımıla 2003 yılı itibariyle sunmaktadır, dolayısıyla çalıșmanın başlangıç y1lı olarak 2003 seçilmiştir. Şekil 2, çalışmada kullanılan verileri grafiksel olarak göstermektedir. Y1llar itibariyle bakıldığında, tarımsal hasılada düzenli bir büyüme gözlenmektedir. Buna paralel olarak, tarımsal ArGe harcamaları da artış göstermiştir. Diğer bir deyişle, bu iki değişkenin zaman içinde aynı yönde hareket ettiği açıça görülmektedir. Analizde kullanılan değişkenler GSYİH deflatörü (2009) ile reel değerlere dönüştürülmüş ve modele doğal logaritmaları alınarak sokulmuştur. TÜİK verilerine göre Ar-Ge harcamaları, finans kaynağ bakımından, kamu ve kamu-dıșı olarak iki ana grupta toplanabilir. Türk tarım sektöründe, 20032017 yılları arasında yapılan harcamaların ortalama \% 89'u kamu dişı sektör tarafından yapılan harcamalardan, ortalama \% 11'i ise kamu tarafindan yapılan harcamalardan oluşmaktadır. Yıllar içinde kamunun harcamalardaki payı artsa da kamu dış1 sektörler hala Ar-Ge harcamalarında ön plandadır.

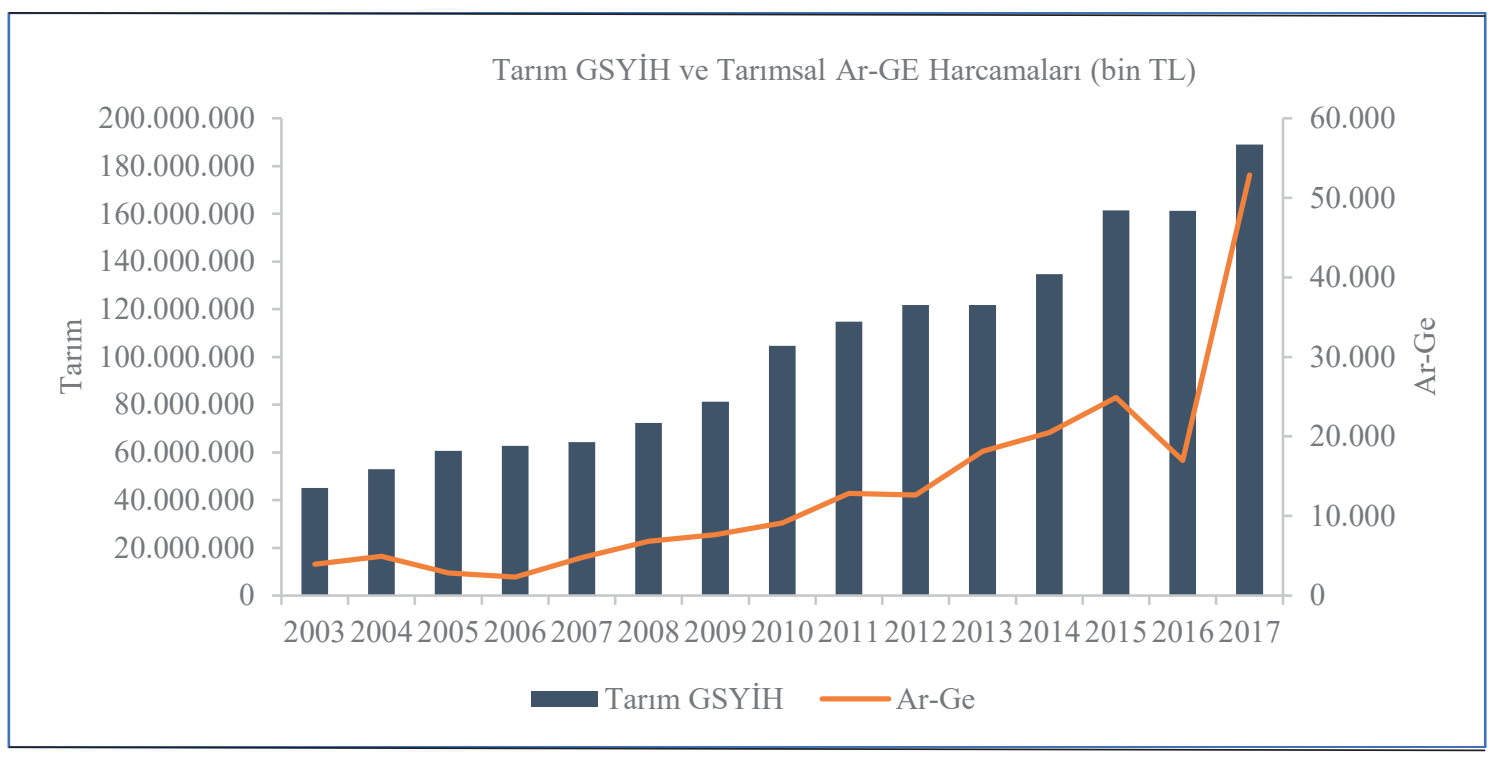

Şekil 2. Çalışmada kullanılan veriler, 2003-2017 (Anonim, 2018) 


\subsection{Yöntem}

$\mathrm{Bu}$ çalışmada, Türkiye tarım endüstrisindeki Ar-Ge harcamaları ile tarımsal büyüme arasındaki nedensellik ilişkisi incelenmiştir. Nedensellik testlerinden önce, zaman serisi verilerinin durağanlığını ölçmek için birim kök testleri uygulanmış, test sonuçlarına göre veriler durağan değil ise, değişkenler arasında doğrusal bir kombinasyonun varlığını belirlemek için eşbütünleşme analizi yapılmıştır. Son olarak, iki zaman serisi arasında bir eşbütünleşme ilişkisinin varlığı durumunda, değișkenler arası Grangernedensellik, vektör hata düzeltme modeli kullanılarak test edilmiştir.

Guilkey ve Salemi (1982) ve Geweke ve ark. (1983), ortaya koydukları Monte Carlo bulguları ile Granger nedensellik testlerinin, küçük örneklem durumunda diğer birçok yönteme nazaran güvenilir sonuçları verdiğini göstermişlerdir. Bu nedenle, bu çalışmada tarımsal Ar-Ge harcamaları ile tarımsal büyüme arasındaki ilişkiyi analiz etmek için Granger nedensellik testi kullanılmıș ve analiz için Hong (2017) çalışmasında kullanılan yöntem takip edilmiştir. Stock ve Watson (1989), durağan olmayan zaman serisi verilerinin sahte regresyona neden olabileceğini öne sürmüştür. Bu da güvenilir bir analiz için durağan zaman serisi verilerinin varlığını gerektirmektedir. Ekonomik zaman serisi değișkenleri genellikle durağan olma eğiliminde olmadığından öncelikle çalışmada kullanılan zaman

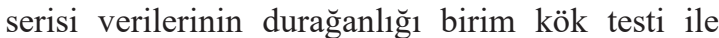
değerlendirmiştir.

\subsubsection{Birim kök testi}

Belirli bir değişkenin bir birim kökü varsa, bu değişkenin tesadüfi bir yürüyüş takip ettiği söylenebilir ve bu değişken fark metodu kullanılarak durağan bir değişkene dönüştürülebilir. Bilimsel literatürde birim kök testi olarak kullanan testler; Dickey-Fuller (DF) testi, Genișletilmiş Dickey-Fuller (ADF) testi ve Phillips-Perron (PP) testleridir. Bunlardan, DF testi, düzeltme teriminin otokorelasyon ve değişen varyans içermediğini varsaydığ 1 için oldukça sınırlı bir testtir. Buna ek olarak, Schwert (1987), PP testinin zaman serilerinin durağan olmadığı hipotezini reddetme eğilimi nedeniyle ADF testinin kullanılmasını önermiş, Davidson ve MacKinnon (2004) ise ADF testinin küçük örneklemler için PP testinden daha üstün olduğunu iddia etmektedir. $\mathrm{Bu}$ nedenle çalışmada, modele gecikmeli bağımlı değişkenler eklemek suretiyle düzeltme terimindeki olası otokorelasyonu hesaba katan ADF testi kullanılmıştır.
Birim kök testlerinde gecikme değerleri artırılırsa, modelin yanlılığı azalır; fakat varyansta artış yaşanır. Diğer taraftan, gecikmeler kısa vade ile sınırlıysa, birim kök testlerinin yanlılığı artar. Bu sorunları çözmek ve en uygun gecikme uzunluğunu seçmek için bazı standartlar oluşturulmalıdır. Genel olarak, birim kök testlerinde Akaike Bilgi Kriteri (AIC: Akaike's Information Criterion) veya Schwartz Bilgi Kriteri (SIC: Schwarz Information Criterion) gecikme uzunluğu belirlemek için kullanılmaktadır. Çalışmada, optimum gecikme uzunluğu için 4 farklı bilgi kriterinden; FPE (Final Prediction Error) (Akaike, 1969), AIC (Akaike, 1973), HQIC (Hannan-Qiunn Criterion) (Hannan ve Quinn, 1979) ve SIC (Schwarz, 1978) faydalanılmıştır.

\subsubsection{Eşbütünleşme testi}

Birim köklere sahip, durağan olmayan zaman serisi verileri arasında kararlı bir doğrusal kombinasyon varsa, bu doğrusal kombinasyon eşbütünleșme olarak adlandırılır. Zaman serileri arasındaki uzun vadeli ilişkiler, gecikme değerleri içeren regresyon analizi ile test edilirse, ilişki ile ilgili önemli bilgiler kaybolmaktadır. Bu nedenle, ekonomik değişkenlerin analizi için eşbütünleşme testlerinin kullanımı daha uygundur. Başka bir deyişle, eşbütünleşme testleri yapılarak sahte regresyondan kaçınılabilir.

Eşbütünleşme testleri, regresyon kalıntı (residual)-bazlı test ve denklem-bazlı test olarak sinıflandirılabilir (Hong, 2017). Kalıntı bazlı eşbütünleşme testleri, birim kök testleri yardımıyla regresyon kalıntısının kararlılığını belirler ve iki aşamalı Engle-Granger (EG-ADF) prosedürünü ve Phillips-Ouliaris (PO) testini içerir. Denklem-bazlı testler ise, iki veya daha fazla eşbütünleşme ilişkisi varlığında uygulanır ve en iyi örneği Johansen testidir. En üstün eşbütünleşme testi olarak kabul edilen Johansen testi, eşbütünleşme parametresini tahmin etmenin yanı sıra çeşitli hipotez testlerini de mümkün kılmaktadır (Hong, 2017). Gonzalo (1994) yaygın olarak kullanılan beş eşbütünleşme testini karşılaştırdığ1 çalışmasında, Johansen (1988) ve Johansen ve Juselius (1988) tarafindan önerilen en yüksek olabilirlik metodunun en etkili yöntem olduğunu belirlemiştir. $\mathrm{Bu}$ nedenle, çalışmada Ar-Ge harcamaları ve ekonomik büyüme zaman serisi değişkenlerinin eşbütünleşme analizinde Johansen yöntemi kullanılmıştır.

Eşbütünleşme testlerinde, birim kök testlerinde olduğu gibi, yanlılığı azaltmak ve doğru sonuçlara ulaşmak için optimum gecikmeler seçilmelidir. Optimum gecikmeleri belirlemek için bilgi kriterlerinden faydalanılmıştır. 
2.2.3. Vektör hata düzeltme modeli nedensellik analizi

İki değişken arasında eşbütünleşme olduğunda nedensellik analizi, hata düzeltme terimi içeren bir hata düzeltme modeli kullanılarak yapılmalıdır. Granger nedensellik analizi eşbütünleşmenin varlığı dikkate alınmadan yapılırsa nedensellik ilişkisini doğru şekilde belirleyemez. Hata düzeltme modeli, kısa ve uzun dönem nedenselliği eşzamanlı olarak inceleme yeteneğine sahiptir. Çünkü sadece bağımsız değişkenlerin gecikme değerleri arasındaki farklarının bağımlı değerler üzerindeki etkilerini değil, aynı zamanda hata düzeltme terimindeki değişikliklerin de bağımlı değişkenler üzerindeki etkilerini kapsar (Hong, 2017).

Hata düzeltme terimi içeren nedensellik analizi, Eşitlik 1 ve 2'de gösterildiği gibi ifade edilebilir.

$\Delta Y_{t}=\alpha_{1}+\sum_{i=1}^{L_{11}} \beta_{11} \Delta Y_{t-i}+\sum_{j=1}^{L_{12}} \beta_{12} \Delta X_{t-j}+\gamma_{1} \hat{\mathrm{e}}_{t-1}+\mu_{1 t}$

$\Delta X_{t}=\alpha_{2}+\sum_{i=1}^{L_{21}} \beta_{21} \Delta Y_{t-i}+\sum_{j=1}^{L_{22}} \beta_{22} \Delta X_{t-j}+\gamma_{2} \hat{\mathrm{e}}_{t-1}+\mu_{2 t}$

$\mathrm{Bu}$ eşitlikler vektör hata düzeltme modeli (VECM) olarak adlandırılır. Eşitliklerde L, en uygun gecikme; $\hat{\mathrm{e}}_{t-1}$, hata düzeltme terimi ve $\mu_{t}$ ise hata terimidir. Eşitlik 1, $\mathrm{X}$ değişkeninden $\mathrm{Y}$ değişkenine olan nedenselliği temsil etmektedir. Eşitlik 1'deki, $\beta_{12}$ katsayısı anlamlı olarak sıfırdan farklı bulunursa, $\mathrm{X}$ değişkeninden $\mathrm{Y}$ değişkenine kısa dönemli Granger nedensellik var demektir. Hata düzeltme teriminin katsayıs $\left(\gamma_{1}\right)$ dengeye doğru ayarlama hızını gösterir. Eğer, $\gamma_{1}$ katsayısı anlamlı olarak sifirdan farklı bulunursa, $\mathrm{X}$ değişkeninden $\mathrm{Y}$ değişkenine uzun dönemli Granger nedenselliğin varlığını belirtir. Eşitlik 2 ise $\mathrm{Y}$ değişkeninden $\mathrm{X}$ değişkenine olan nedenselliği temsil etmektedir. $\beta_{22}$ ve $\gamma_{2}$ katsayılarının anlaml olarak sifirdan farklı bulunması halinde ise $\mathrm{Y}$ değişkeninden $\mathrm{X}$ değişkenine sırasıyla kısa dönemli ve uzun dönemli Granger nedenselliğin varlığı sonucuna varilir.

Hata düzeltme modelini kullanarak nedenselliği test etmek için önce bağımsız değişkenlerin gecikme uzunluğu belirlenmelidir. Gecikme uzunluğu, test sonuçları üzerinde önemli bir etkiye sahip olabileceğinden, doğruluğu sağlamak için dikkatlice seçilmelidir. Optimum gecikme uzunlukları yine belirtilen bilgi kriterlerine göre belirlenmiştir.

\section{Bulgular}

\subsection{Birim kök testleri}

Tarımsal GSYİH ve Ar-Ge harcamaları zaman serisi verileri için ADF birim kök testlerinin sonuçları Tablo 1'de verilmiştir. ADF test sonuçlarına göre hem tarımsal GSYİH hem de ArGe harcamaları birim köke sahiptir. Test sonuçları, \% 1 anlamlılık düzeyinde kritik değerin altında kaldığı için birim kök olmadığını öne süren boş hipotez her iki zaman serisi değişkeni için de reddedilmiştir.

Tablo 1. Birim kök testi sonuçları

\begin{tabular}{lc}
\hline Değişken & $\begin{array}{c}\text { Genişletilmiş Dickey- } \\
\text { Fuller }\end{array}$ \\
\hline Tarımsal GSYİH & -1.169 \\
\hline Ar-Ge Harcamaları & -0.587 \\
\hline$\% 1$ anlamlılık düzeyinde kritik değer: -3.75 &
\end{tabular}

\subsection{Eşbütünleşme testi}

Eşbütünleşme testi ve hata düzeltme modeli için öncelikle optimum gecikme uzunluklarını belirlemek gereklidir. Optimum gecikme uzunluğu için dört farklı bilgi kriteri sonuçları Tablo 2'de gösterilmektedir. Tabloya göre dört bilgi kriterinin üçü optimum gecikme uzunluğunu dört olarak belirlemektedir. Dolayısıyla, Johansen eşbütünleşme ve VECM analizlerinde gecikme uzunluğu dört olarak kullanılmıştır.

Tablo 2. Optimum gecikme uzunluğu

\begin{tabular}{ccccc}
\hline $\begin{array}{c}\text { Gecikme uzunluğu } \\
\text { /Kriter }\end{array}$ & FPE & AIC & HQIC & SIC \\
\hline 1 & 0.0082 & -1.4546 & 1.5914 & -1.2375 \\
2 & $0.0004^{*}$ & -2.1595 & -2.3875 & -1.7978 \\
3 & 0.0007 & -2.0113 & -2.3305 & -1.5049 \\
4 & 0.0007 & $-2.8387^{*}$ & $-3.2491^{*}$ & $-2.1876^{*}$ \\
\hline
\end{tabular}

*: en düşük değer

Eşbütünleşme testi için bir model seçerken, zaman serileri için deterministik bir trend olmadığ varsayımı yapılmıştır. Ar-Ge harcamaları ile tarımsal hasıla arasındaki eşbütünleşme testinin bulguları Tablo 3'te sunulmaktadır. Sonuçlara göre, eşbütünleşmenin \% 5 anlamlılık düzeyinde bulunmadığını öngören boş hipotez $\left(H_{0}: \mathrm{R}=0\right)$ reddedilmekte, yani eşbütünleşmenin değişkenler arasında bulunduğu görülmektedir. Ayrıca, bir eşbütünleşmenin var olduğunu öne süren boş hipotez $\left(H_{0}: \mathrm{R} \leq 1\right)$ reddedilememekte, bu da yine bir eşbütünleşmenin var olduğu anlamına gelmektedir.

Tablo 3. Johansen Eşbütünleşme bulguları

\begin{tabular}{ccccc}
\hline $\begin{array}{c}\text { Boş } \\
\text { hipotez }\end{array}$ & $\begin{array}{c}\text { Maksimum } \\
\text { özdeğer } \\
\text { testi }\end{array}$ & $\begin{array}{c}\text { Maksimum } \\
\text { özdeğer } \\
\text { testi }\end{array}$ & $\begin{array}{c}\text { İz } \\
\text { testi }\end{array}$ & $\begin{array}{c}\text { İz } \\
\text { testi }\end{array}$ \\
\hline Rank & $\begin{array}{c}\text { Test } \\
\text { istatistiği }\end{array}$ & $\begin{array}{c}\text { Kriter } \\
\text { değer }\end{array}$ & $\begin{array}{c}\text { Test } \\
\text { istatistiği }\end{array}$ & $\begin{array}{c}\text { Kriter } \\
\text { değer }\end{array}$ \\
\hline$=0$ & 21.1618 & 14.07 & 21.5126 & 15.41 \\
$\leq 1$ & 0.3508 & 3.76 & 0.3508 & 3.76 \\
\hline
\end{tabular}




\subsection{Vektör hata düzeltme modeli nedensellik analizi}

Eşbütünleşme modeline benzer şekilde, hata düzeltme modeli içeren Granger nedensellik analizi için de deterministik bir trend olmadığ 1 varsayımı yapılmıştır. Optimum gecikmenin seçiminde, Tablo 2'de gösterildiği gibi dört gecikme uzunluğu seçilmiştir. Tablo 4, VECM kullanılarak yapılan Granger nedensellik analizinin sonuçlarını ortaya koymaktadır.

Test sonuçları, Ar-Ge harcamaları ve tarımsal hasıla arasında uzun dönemli nedenselliğin varlığını ortaya koymaktadır. Ar-Ge harcamaları hata düzeltme teriminin katsayısı (-0.22), \% 1 düzeyinde istatistiksel olarak anlamlıdır. Bu da uzun dönemde Ar-Ge harcamalarının tarımsal hasılayı pozitif etkilediğini göstermektedir. Ar-Ge harcamalarından tarımsal GSYİH'ye olan kısa dönem nedenselliğini gösteren $\mathrm{F}$ istatistiği de \% 1 düzeyinde istatistiksel olarak anlamlıdır. Tarımsal GSYİH hata düzeltme teriminin katsayısı (-4.54), ise tarımsal hasılanın Ar-Ge harcamalarını uzun dönemde pozitif etkilediğini ortaya koymaktadır. Kısa dönem nedensellik sonucuna göre ise tarımsal hasıla tarımsal Ar-Ge harcamalarının nedenidir. Jarque-Bera normallik testi hata düzeltme modeli kalıntılarının normal dağılım gösterdiğini, analizde otokorelasyon ve değişen varyans problemleri bulunmadığını belirtmektedir.

Tablo 4. VECM-Granger nedensellik bulguları

\begin{tabular}{lccc}
\hline Boş hipotez & Test istatistiği & $\begin{array}{c}\text { Kisa dönem } \\
\text { nedensellik }\end{array}$ & $\begin{array}{c}\text { Uzun dönem } \\
\text { nedensellik }\end{array}$ \\
\hline $\begin{array}{l}\text { Ar-Ge harcamaları, tarımsal hasılanın Granger } \\
\text { nedeni değildir. }\end{array}$ & F-istatistiği & - & $-0.22^{*}$ \\
\hline & $\begin{array}{c}\text { Hata düzeltme } \\
\text { katsayısı }\end{array}$ & $1^{*}$ & $19.36^{*}$ \\
$\begin{array}{l}\text { Tarımsal hasıla, Ar-Ge harcamalarının } \\
\text { Granger nedeni değildir. }\end{array}$ & F-istatistiği & - \\
& $\begin{array}{c}\text { Hata düzeltme } \\
\text { katsayısı }\end{array}$ & $-4.54^{*}$ \\
\hline
\end{tabular}

*:\% 1 düzeyinde istatiksel anlamlılık

\section{Tartışma ve Sonuc}

Çalışmanın sonuçları, tarım Ar-Ge harcamaları ile tarımsal hasıla arasında iki yönlü nedensellik olduğunu ortaya koymaktadır. Yani Ar-Ge harcamaları tarım sektörünün büyümesine, tarım sektörünün büyümesi de Ar-Ge harcamalarının artmasına neden olmaktadır. Sonuçlar, Ar-Ge harcamalarının, tarımsal verimlilik ve büyümeye pozitif ve anlamlı katkısı olduğunu savunan Alene (2010), Andersen (2015) ve Rao ve ark. (2019) ile uyumludur. Subaşı ve Ören (2013), Türk tarım sektöründe Ar-Ge harcamaları ve tarımsal büyüme değişkeni olarak kullandıkları toplam faktör verimliliği arasındaki nedensellik ilişkisinin tek yönlü olduğunu göstermektedir. $\mathrm{Bu}$ çalışmanın sonuçları ise Subaşı ve Ören (2013)'den değişkenler arası nedenselliğin yönü ile farklılık göstermektedir. Özaydın ve Çelik (2019), tarıma yönelik Ar-Ge faaliyetlerinin dünyada 2023 y1lına kadar artan oranda artacağını ve bunun tarımsal büyüme ve kalkınmayı olumlu yönde etkileyeceğini öngörmektedir. Çalıșma, Özaydın ve Çelik (2019)'in öngörülerini ampirik olarak desteklemektedir.

Günümüz dünyasında yaşanan dönüşümün yansıması olarak diğer ekonomik faaliyetlerde olduğu gibi, tarımsal faaliyetlerde de inovasyonun, verimlilik artışının, ekonomik büyüme ve kalkınmanın ana motoru Ar-Ge harcamalarıdır. Çalışmanın hem grafiksel hem de ekonometrik analiz sonuçları, Ar-Ge harcamalarının tarım sektöründe büyümeyi kısa ve uzun dönemde pozitif ve anlamlı olarak etkilediğini göstermektedir. Çalışmada kullanılan veriler, nispeten kısa bir dönem olan 2003-2017 yılları arasını kapsamaktadır. Sonuçlar istatistiksel olarak anlamlı olmakla beraber, gelecekte yapılacak daha geniş veri seti kullanan çalışmalar, bu çalıșmanın bulgularını kuvvetlendirecektir.

Türkiye'de kamu kurumları, mali ve mali olmayan şirketler, yüksek öğretim kurumları ve diğer kuruluşlar tarafından yapılan tarımsal Ar-Ge harcamaları, 2003 y1lından itibaren artarak devam etmektedir. Türkiye, dünya tarım ve hayvancıllk piyasasında önemli bir paya sahip olmasına rağmen, yapılan Ar-Ge harcamaları istenilen düzeyde değildir (Özaydın ve Çelik, 2019). Bu kapsamda, Türkiye tarım sektörünün sürdürülebilir bir büyümeyi devam ettirmesi ve uluslararası düzeyde rekabet gücünü koruması için Ar-Ge harcamalarının artarak devam etmesi gerekmektedir. Artan Ar-Ge harcamaları, tarım sektöründe verimlilik artışı sağlayacak ve ekonomik büyümeye önemli katkı sağlayacaktır. 


\section{Kaynaklar}

Akaike, H., 1969. Fitting autoregressive models for prediction. Annals of the Institute of Statistical Mathematics, 21: 243-247.

Akaike, H., 1973. Information theory and an extension of the maximum likelihood principle. 2nd International Symposium on Information Theory by B.N. Petrov and F. Csaki (Eds.), Akademiai Kiado: Budapest.

Alene, A.D., 2010. Productivity growth and the effects of $\mathrm{R} \& \mathrm{D}$ in African agriculture. Agricultural Economics, 41(3-4): 223-238.

Alston, J.M., Beddow, J.M., Pardey, P.G., 2009. Agricultural research, productivity, and food prices in the long run. Science, 325(5945): 1209-1210.

Andersen, M.A., 2015. Public investment in US agricultural R\&D and the economic benefits. Food Policy, 51: 38-43.

Anonim, 2018. Türkiye'de Tarımsal Ar-Ge Harcamaları. Türkiye İstatistik Kurumu, (http://www.tuik.gov.tr/), (Erişim tarihi: 28.09.2019).

Anonymous, 2017. The Future of Food and Agriculture: Trends and Challenges. Annual Report. (http://www. fao.org/3/a-i6583e.pdf), (Erişim tarihi: 28.09.2019).

Bayaner, A., 2016. Tarımsal Ar-Ge ve ekonomik büyüme. Türkiye Tohumcular Birliği Dergisi, 19: 913.

Cinemre, H.A., Kılıç, O., 2015. Tarım Ekonomisi (5. Bask1). Ondokuz May1s Üniversitesi, Ziraat Fakültesi, Ders Kitabı No: 11, Samsun.

Davidson, R., MacKinnon, J.G., 2004. Econometric Theory and Methods (Vol. 5). New York, Oxford University Press.

Doğan, Z., Arslan S., Berkman A., 2015. Türkiye'de tarım sektörünün iktisadi gelișimi ve sorunları: Tarihsel bir bakış. Niğde Üniversitesi İktisadi ve İdari Bilimler Fakültesi Dergisi, 8(1): 29-41.

Eryılmaz, G.A., Kılıç, O., 2018. İyi tarım uygulamalarının konvansiyonel tarım yapan işletmelerdeki optimum organizasyona etkisi: Samsun İli Bafra İlçesi örneği. Adnan Menderes Üniversitesi Ziraat Fakültesi Dergisi, 15(1):101-106.

Eryılmaz, G.A., Kılıç, O., Boz, İ., 2019. Türkiye'de organik tarım ve iyi tarım uygulamalarının ekonomik, sosyal ve çevresel sürdürülebilirlik açısından değerlendirilmesi. Yüzüncü Yll Üniversitesi Tarım Bilimleri Dergisi, 29(2): 352-361.

Geweke, J., Meese, R., Dent, W., 1983. Comparing alternative tests of causality in temporal systems: analytic results and experimental evidence. Journal of Econometrics, 21(2): 161-194.

Gonzalo, J., 1994. Five alternative methods of estimating long-run equilibrium relationships. Journal of Econometrics, 60(1-2): 203-233.
Guilkey, D.K., Salemi, M.K., 1982. Small sample properties of three tests for Granger-causal ordering in a bivariate stochastic system. The Review of Economics and Statistics, 64(4): 668-680.

Hannan, E.J., Quinn, B.G., 1979. The determination of the order of an autoregression. Journal of the Royal Statistical Society: Series B (Methodological), 41(2): 190-195.

Hong, J.P., 2017. Causal relationship between ICT R\&D investment and economic growth in Korea. Technological Forecasting and Social Change, 116: 70-75.

Johansen, S., 1988. Statistical analysis of cointegration vectors. Journal of Economic Dynamics and Control, 12(2-3): 231-254.

Johansen, S., Juselius, K., 1988. Hypothesis Testing for Cointegration Vectors: With Application to The Demand for Money in Denmark and Finland. Discussion Paper 8805, University of Copenhagen, Copenhagen.

Owens, T., Hoddinott, J., Kinsey, B., 2003. The impact of agricultural extension on farm production in resettlement areas of Zimbabwe.Economic Development and Cultural Change, 51(2): 337-357.

Özaydın, G., Çelik, Y., 2019. Tarım sektöründe Ar-Ge ve inovasyon. Tarm Ekonomisi Dergisi, 25(1): 1-13.

Pardey, P.G., Alston, J.M., Chan-Kang, C., 2013. Public agricultural R\&D over the past half century: an emerging new world order. Agricultural Economics, 44(1): 103-113.

Rao, X., Hurley, T.M., Pardey, P.G., 2019. Are agricultural R\&D returns declining and development dependent? World Development, 122: 27-37.

Ray, D.K., Mueller, N.D., West, P.C., Foley, J.A., 2013. Yield trends are insufficient to double global crop production by 2050. PloS One, 8(6): e66428.

Schwarz, G., 1978. Estimating the dimension of a model. Annals of Statistics, 6: 461-464.

Schwert, G.W., 1987. Effects of model specification on tests for unit roots in macroeconomic data. Journal of Monetary Economics, 20(1): 73-103.

Stock, J.H., Watson, M.W., 1989. Interpreting the evidence on money-income causality. Journal of Econometrics, 40(1): 161-181.

Subaşı, O.S., Ören, M.N., 2013. Türkiye'de tarımsal ArGe harcamaları ve tarımsal büyüme ilişkileri. Akdeniz Üniversitesi Ziraat Fakültesi Dergisi, 26(2): 99-104.

Tilman, D., Balzer, C., Hill, J., Befort, B.L., 2011. Global food demand and the sustainable intensification of agriculture. Proceedings of the National Academy of Sciences, 108(50): 20260-20264. 